This item was submitted to Loughborough's Research Repository by the author.

Items in Figshare are protected by copyright, with all rights reserved, unless otherwise indicated.

\title{
Response: resilient times
}

\section{PLEASE CITE THE PUBLISHED VERSION}

http://dx.doi.org/10.1080/21693293.2016.1189137

\section{PUBLISHER}

(C) Taylor \& Francis

\section{VERSION}

AM (Accepted Manuscript)

\section{PUBLISHER STATEMENT}

This work is made available according to the conditions of the Creative Commons Attribution-NonCommercialNoDerivatives 4.0 International (CC BY-NC-ND 4.0) licence. Full details of this licence are available at: https://creativecommons.org/licenses/by-nc-nd/4.0/

\section{LICENCE}

CC BY-NC-ND 4.0

\section{REPOSITORY RECORD}

Zebrowski, Chris. 2019. “Response: Resilient Times”. figshare. https://hdl.handle.net/2134/21735. 


\section{Authors Response: Resilient Times}

\section{Chris Zebrowski}

I would like to begin by thanking each of the reviewers for such careful and provocative readings. I'm delighted that the book was well-received and even happier to see the new lines of questioning it has provoked-well beyond those which preoccupied me when writing it. Given the limited space available I will not, unfortunately, be able to address all of the questions and concerns raised in the reviews. Instead, I would like to use this response section to address a series of questions running across all three reviews concerning the relation between time/temporalities, politics and resilience.

How can we account for the value of resilience? This is the question I pose in my book. For its advocates, the value of resilience is self-evident. Resilience promises to provide a degree of security within an increasingly uncertain and dangerous world. For its detractors, the value of resilience is wholly negative. Resilience functions as ideology-promoting a neoliberal agenda in which security responsibilities are offloaded from the State onto citizens. In both cases, resilience is understood to be a stable concept whose value can be readily ascertained through a calculation of its utility within present circumstances. However, in practice, resilience appears to be anything but stable. Multiple, often conflicting, meanings of this concept are enacted across academic disciplines and professional bodies.

Rather than approach resilience as a concept whose value could be ascertained once we established its proper meaning, I was interested in understanding the historical processes through which the meaning(s) and value of resilience emerged over time. Specifically, I was interested in accounting for the conditions which allowed resilience to emerge as the principle value guiding $21^{\text {st }}$ Century security policy. For this task I turned to genealogy. Rather than approaching resilience as a concept anchored to a determinate sense, I came to understand resilience as an emergent security value. As a value, resilience harbours multiple, evolving and sometimes contradictory senses. This diversity is often productive: allowing multiple agents to harmonize their disparate activities under the guise of achieving a common goal. In performing a genealogy of resilience, I sought to identify and analyse the contingent, and often obscure, political processes through which these diverse meanings, and ultimately the value of resilience itself, were historically assembled. The point wasn't to advance a truer conceptualization of resilience and its value. It was instead to unsettle some of our presumptions about the meaning and value of resilience for the sake of opening this concept to increasingly critical, experimental and creative engagements to come.

It is important to stress that this book does not provide an exhaustive account of the history of resilience. For the sake of empirical precision certain decisions were made to restrict my focus. One of these decisions was to focus my investigation on the evolution of a British machinery of emergency governance. This meant tracing the institutional history of UK Civil Contingencies to its inception as a secret strike-breaking organization in the final years of the First World War. I looked to identify the historical problematics which spurred organizational changes and traced the migration of ideas relating to security, protection and resilience into and out of this empirical field. Restricting my empirical focus permitted me to describe, with a sufficient degree of detail, how ideas related to resilience were taken up, translated, adapted and modified within the particular political and social environment of the UK. But it also undoubtedly meant disregarding other rich lines of inquiry in the history of resilience. Even within the British context, major events including the 1981 Brixton 'riots' (which Alison identifies), the 1984-85 miner's strikes and the history of policing football 'hooliganism' were excluded-not because they weren't integral to the history of UK Civil Contingencies, but due to restrictions still in place on public access to the official government 
archives covering these years. It goes without saying that a detailed analysis of these archives and especially those pertaining to Britain's imperial past would provide substantial insight into the historical evolution of UK Civil Contingencies.

It is in respect to the (underemphasized) importance of history and memory to contemporary logics of resilience that genealogy was selected as a method and a memorial selected as the book's cover art. The 7/7 memorial in Hyde Park provides a prominent visual representation of how resilience is specifically deployed within the British context. The memorial consists of 52 individualized sterlae (stainless steel pillars) erected in remembrance of each of the individuals who lost their lives in terrorist attacks in London on 7 July 2005. The impermeable steel pillars project a sense of strength through loss; that something of who we are persists-or perhaps is even strengthened-through the destruction of our vulnerable material bodies. The play of temporalities here, as Charlotte adeptly notes, is curious. As a memorial, this installation refers to a discrete past event. Yet it operates as a device for forging a collective memory of how this event should be understood. In doing so, it seeks to project a vision of collective resilience which simultaneously tells us who we are and what we should aspire to be. These complicated temporalities suggest, as Charlotte is correct to point out, that resilience cannot be circumscribed to an anticipatory technology of governance without also recognizing the significant role that history and memory play in its actualization. I attempted to analyse these relations in the final chapter of the book on Preparedness Exercises. Recognizing that resilience is built through past experience of successfully overcoming crises, the exercise provides a controlled space through which individual and collective capacities-and indeed memories - can be fostered, tested and refined. Resilience, in effect, is as much about preparedness and the structuring of expectation as it is about achieving a perspective on the past that fosters confidence in oneself and those around you. The future is secured by manufacturing a history of success.

Like memorialization, the emergency response strategies of UKCC act to mitigate an event's capacity to disrupt the 'normal' temporal order. Rather than retrospectively working to impose a meaning upon the emergency event supportive of narratives underpinning (state) order (Edkins 2006), resilience strategies operate to quickly foreclose the duration, extension and intensity of an unfolding event. In my analysis I tried to show how the reorganization of UK Civil Contingencies borrowed heavily from concurrent military developments associated with the Revolution in Military Affairs (RMA). The advantage afforded by these reforms, I argued, was ultimately an acceleration of the speed of command. Nick is correct to identify Virilio as a silent interlocutor here. However, as much as Virilio helped to orient my analysis I was wary of following him too far down his line of critique. As Alison notes, I have been somewhat averse to the claim that the advent of resilience marks a militarization of emergency governance. This is, in fact, a very old critique which has resurfaced many times throughout the history of UK Civil Defence and Civil Contingencies. While not unfounded (there has indeed been a heavy military presence in all aspects of civil contingencies from its inception in the UK) Alison is correct to identify that the problem with this line of critique is that it often leaves what is meant by 'militarization' underspecified. This is the same problem we encounter with analyses equating resilience with neoliberalism - as if the meaning of neoliberalism was any more self-evident than the idea of resilience! The question for me throughout the book was always therefore to be specific as to which concepts, strategies and practices carried over from the military into the domain of emergency governance (and vice-versa).

Registering the influx of military ideas into contemporary civil contingencies operations provides valuable insight into the logics and practices of contemporary emergency governance and the wider political economy within which these changes operate. Yet, these changes to both military and civil contingencies organization cannot be fully accounted for without the introduction of a third term: 
strategic business management. This is, in retrospect, an important aspect in the genealogy of resilience that I feel was underemphasized in the book. Of course, military theorists of the RMA from Cebrowski to Ronfelt and Arquilla were fascinated by developments in International Business organization and strategy, whilst the vast majority of books published in the area of resilience are self-help books marketed to entrepreneurs and middle-managers. Recognizing the influence of business managerial discourses in shaping resilience thinking may, in turn, have implications for our strategies of critique. Overemphasizing the spectre of war may inadvertently push critique to uncover the dark, necropolitical underside of resilience. Critique once again strains to locate the hidden meaning which reveals resilience for what it is. Strategic business management is, by contrast, far less spectacular. While championing the ability of network-enabled communications to enhance dynamic capabilities, creativity and self-organization it is clear that by circumscribing these terms within the constraints of profit-maximization fundamental limits are placed on the capacity of these terms to be fully actualized. The specific ways in which resilience is currently enacted arguably limits the ability of this concept to achieve its promised goals. This raises the question as to whether resilience could be interpreted and enacted otherwise.

In the book's conclusion I offer some very preliminary ideas on what I term an affirmative critique of resilience. An affirmative critique of resilience would start from the recognition that resilience has no inherent meaning or value because it is still very much in the process of becoming. An affirmative critique of resilience would therefore look to experiment with the concept by repeating it differently: by mimicking it; linking it to new objectives and transforming it fundamentally in the process. Can we observe resilience-related ideas within projects distinct from, or even opposed to, neoliberal programmes of governance? In what ways can resilience be reinterpreted in a way that inspires greater communication, creativity and self-organization? What would it mean for us to be truly resilient? Of course, such a line of critique is not without its own dangers. However dispensing with a critique based on binary opposition - in which one must be either for or against resiliencemay open up new avenues for political expression and contestation in the contemporary security environment. 